\title{
Heat of Formation of Titanium Tetraiodide
}

\author{
W. H. Johnson, A. A. Gilliland, and E. J. Prosen
}

(May 6, 1959)

\begin{abstract}
The heat of formation of titanium tetraiodide was determined relative to that of titanium tetrabromide by comparison of their heats of hydrolysis in dilute sulfuric acid. The difference in the heats of formation may be expressed by the equation:

$$
\begin{gathered}
\mathrm{TiI}_{4}(\mathrm{c})+2 \mathrm{Br}_{2}(\mathrm{liq})=\mathrm{TiBr}_{4}(\mathrm{c})+2 \mathrm{I}_{2}(\mathrm{c}), \\
\Delta H\left(25^{\circ} \mathrm{C}\right)=-230.91 \pm 0.75 \mathrm{kj} / \text { mole }(-55.19 \pm 0.18 \mathrm{kcal} / \mathrm{mole}) .
\end{gathered}
$$

By taking the heat of formation of $\mathrm{TiBr}_{4}(\mathrm{c})$ as $-616.72 \pm 4.60 \mathrm{kj} / \mathrm{mole}$, the heat of formation of $\mathrm{TiI}_{4}(\mathrm{c})$ is calculated to be $-385.81 \pm 4.64 \mathrm{kj} / \mathrm{mole}(-91.21 \pm 1.11 \mathrm{kcal} / \mathrm{mole})$. The heats of hydrolysis of $\mathrm{TiBr}_{4}$ and $\mathrm{TiCl}_{4}$ were similarly measured; the value obtained for the difference $(186.77 \pm 1.34 \mathrm{kj} / \mathrm{mole})$ is in good agreement with the difference between the directly determined heats of formation (187.11 $\pm 5.35 \mathrm{kj} / \mathrm{mole})$.
\end{abstract}

\section{Introduction}

There are no experimental values available in the literature for the heat of formation of titanium tetraiodide. Brewer, Bromley, Gilles, and Lofgren [1] ${ }^{1}$ calculated the heat of formation from estimated heats of solution and lattice-energy calculations. They obtained $-101 \pm 10 \mathrm{kcal} / \mathrm{mole}$ for the heat of formation of $\mathrm{TiI}_{4}$ at $25^{\circ} \mathrm{C}$.

The direct combination of elemental titanium with gaseous iodine is not feasible because of the low vapor pressure of iodine at ordinary temperatures; at higher temperatures, the tetraiodide tends to decompose into $\mathrm{TiI}_{2}$ and $\mathrm{TiI}_{3}[2]$.

The heats of formation of titanium tetrachloride and titanium tetrabromide have recently been determined by the direct combination of the elements in a calorimeter $[3,4]$.

It is possible to hydrolyze $\mathrm{TiI}_{4}$, as well as $\mathrm{TiCl}_{4}$ and $\mathrm{TiBr}_{4}$, in dilute sulfuric acid. We can assume that the final state of the $\mathrm{Ti}^{4+}$ ion is the same in each case and that the differences in the heats of hydrolysis are measures of the differences in the heats of formation. We may, therefore, compare the heats of hydrolysis of $\mathrm{TiI}_{4}$ and $\mathrm{TiBr}_{4}$ and obtain the heat of formation of $\mathrm{TiI}_{4}$ relative to that of $\mathrm{TiBr}_{4}$. We may also compare the heats of hydrolysis of $\mathrm{TiBr}_{4}$ and $\mathrm{TiCl}_{4}$ and obtain the difference between their heats of formation. This value should agree with the difference between the directly determined heats of formation.

The present investigation is comprised of two parts. The first part consists of the measurement of the heats of hydrolysis of $\mathrm{TiI}_{4}$ and $\mathrm{TiBr}_{4}$ and the calculation of the heat of formation of $\mathrm{TiI}_{4}$ relative to that of $\mathrm{TiBr}_{4}$. The second part includes the measurement of the heats of hydrolysis of $\mathrm{TiBr}_{4}$ and $\mathrm{TiCl}_{4}$ and the comparison of the difference between these heats of hydrolysis with the difference between the heats of formation.

\section{Source and Purity of Samples}

The $\mathrm{TiCl}_{4}, \mathrm{TiBr}_{4}$, and $\mathrm{TiI}_{4}$ were prepared by the Inorganic Chemistry Section of the Chemistry Division. The purity of the $\mathrm{TiCl}_{4}$ and $\mathrm{TiBr}_{4}$ was determined to be 99.999 and 99.998 mole percent, respectively, from calorimetric freezing-point measurements conducted by George T. Furukawa of the Thermodynamics Section of the Heat Division. The purity of the $\mathrm{TiI}_{4}$ was determined by analysis to be 99.91 mole percent; this analysis was performed by the Inorganic Chemistry Section of the Chemistry Division.

The $1-N$ sulfuric acid solution used as the calorimetric fluid for the hydrolysis experiments was prepared from concentrated, reagent-grade acid.

The hydrobromic and hydriodic acids were redistilled from reagent-grade solutions; the constantboiling fractions were collected under nitrogen and stored in darkness in completely filled, glass-stoppered bottles. The hydrochloric acid was taken directly from a fresh bottle of reagent-grade acid.

The $\mathrm{TiCl}_{4}$ and $\mathrm{TiBr}_{4}$ were distilled in vacuum into Pyrex glass bulbs, and the bulbs sealed. Soft glass bulbs were filled with the solid $\mathrm{TiI}_{4}$ in a helium atmosphere. The bulbs were then fitted with polyethylene caps, removed from the helium atmosphere, cooled in ice, and sealed. The hydrochloric, hydrobromic, and hydriodic acid solutions were placed in soft glass bulbs by means of a funnel drawn down to a capillary. They were then cooled in ice and sealed.

The quantity of each of the titanium tetrahalide samples was determined by weighing the bulbs before and after filling. The quantities of the hydrobromic and hydriodic acid samples were determined from the mass of the sample and the concentration of the stock solution. The quantities of the hydrochloric acid samples were determined by analysis of the resulting calorimetric solution.

\footnotetext{
1 Figures in brackets indicate the literature references at the end of this paper.
} 


\section{3. Āpparatus and Procedure}

The calorimeter used for measurement of the heats of hydrolysis and dilution is shown in figure 1 . It consists of a glass vessel having a silvered, evacuated

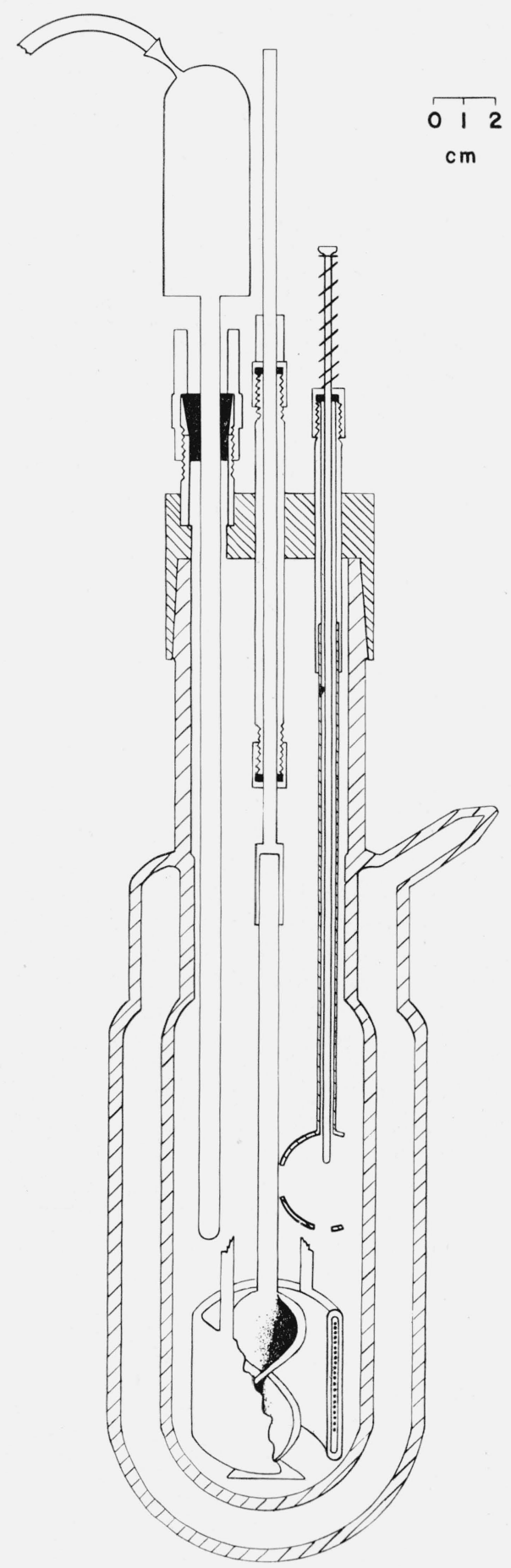

Figure 1. Glass calorimeter. jacket, a glass-enclosed manganin heating coil, a glass stirrer, a glass bulb-crusher, and a glassenclosed platinum resistance thermometer. The upper part of the vessel consists of a $60 / 35$ standardtaper joint; the volume of the enlarged portion is approximately $500 \mathrm{ml}$.

The heating coil, stirrer, bulb-crusher, and platinum thermometer are all supported by the brass head. The resistance of the heating coil is 124.33 ohms. The heater leads, which pass through the supporting tubes, have branch points, similar to a 4-lead thermohm, located approximately midway between the calorimeter and jacket boundaries. The stirrer shaft is constructed of stainless steel and passes through a stainless steel tube fitted at both ends with Teflon gaskets which serve as bearings. The glass stirrer is sealed into a stainless steel cup welded to the stirrer shaft. The calorimetric assembly was immersed in a thermostatically-controlled water bath during each experiment.

The apparatus for measurement of calorimeter temperatures, for calibration with electrical energy, and the details of calorimetric procedures have been described in previous papers [3, 4].

In order to compare the heats of hydrolysis of $\mathrm{TiBr}_{4}$ and $\mathrm{TiI}_{4}$, it was necessary that the composition of the end solution be essentially the same in each case. For this reason 0.04 mole of hydriodic acid was added to the sulfuric acid solution for the $\mathrm{TiBr}_{4}$ hydrolysis experiments, and 0.04 mole of hydrobromic acid was added to the solution for the $\mathrm{TiI}_{4}$ hydrolysis experiments. A similar procedure was used in the determination of the heats of hydrolysis of $\mathrm{TiBr}_{4}$ and $\mathrm{TiCl}_{4}$.

The solutions resulting from the $\mathrm{TiI}_{4}$ hydrolysis experiments were carefully removed from the calorimeter and neutralized with ammonium hydroxide solution. The solution was boiled to coagulate the precipitate which was then filtered and ignited to constant weight and weighed as $\mathrm{TiO}_{2}$. The average ratio of the $\mathrm{TiO}_{2}$ found to the theoretical quantity based upon the weight of sample was $1.0022 \pm$ 0.0028 .

The solutions resulting from the $\mathrm{TiI}_{4}$ hydrolysis experiments and from the hydriodic acid dilution experiments varied in color from faintly amber to brown. After standing for a few hours they became noticeably darker in color, presumably because of oxidation of the hydriodic acid.

The solutions resulting from the $\mathrm{TiBr}_{4}$ hydrolysis experiments and the hydrobromic acid dulition experiments were clear, but usually turned very faintly amber after standing, probably because of oxidation of the hydriodic and hydrobromic acids.

The solutions resulting from the $\mathrm{TiCl}_{4}$ hydrolysis experiments were very slightly turbid, but they became clear after standing for a few hours. This was probably caused by the rapidity of the reaction which, for some unknown reason, varied considerably among experiments. In some cases the violence of the reaction caused liquid to be splashed on the calorimeter walls above the level of the solutions, which made it necessary to reject the experiment. 


\section{Experimental Results}

\subsection{Hydrolysis of $\mathrm{TiI}_{4}$}

The results of the electrical calibration experiments are given in table 1 , where $E$ is the electrical energy, in joules, added to the system; $\Delta R c$ is the corrected temperature rise in ohms; and $E_{s}$ the energy equivalent of the "standard" calorimetric system in joules per ohm.

TABLE 1. Electrical calibration of the $\mathrm{TiI}_{4}$ system

\begin{tabular}{|c|c|c|c|}
\hline Experiment & $E$ & $\Delta R c$ & $E_{s}$ \\
\hline $\begin{array}{l}1 \\
2 \\
3 \\
4 \\
5\end{array}$ & $\begin{array}{l}j \\
4559.62 \\
4554.26 \\
4541.07 \\
451.31 \\
4541.72\end{array}$ & $\begin{array}{l}\text { Ohm } \\
0.208827 \\
.208568 \\
.208038 \\
.210309 \\
.208048\end{array}$ & $\begin{array}{l}\text { j/ohm } \\
21834.4 \\
21833.3 \\
21828.4 \\
2181.3 \\
21830.3\end{array}$ \\
\hline \multicolumn{3}{|c|}{$\begin{array}{l}\text { Mean } \\
\text { Standard deviation of the mean }\end{array}$} & $\begin{array}{r}21831.5 \\
\quad \pm 1.1\end{array}$ \\
\hline
\end{tabular}

The results of the $\mathrm{TiI}_{4}$ hydrolysis experiments are given in table 2 . The quantity $\Delta e$ is the deviation in joules per ohm of the electrical energy equivalent of the actual calorimetric system from that of the calibrated system. This deviation includes the heat capacity of the sample and of the glass bulb, less that of the empty bulb used in the calibration. The energy in joules, $q$, evolved by the process is obtained as the product of $\Delta R c$ and the actual energy equivalent of the system. The heat of hydrolysis, $-\Delta H$ $\left(27^{\circ} \mathrm{C}\right)$, is therefore the ratio of $q$ to the number of moles of sample. For these calculations the heat capacities of ' $\mathrm{I}^{\prime} \mathrm{II}_{4}$ (c) and Pyrex glass were taken as 0.235 and $0.795 \mathrm{j} / \mathrm{g}^{\circ} \mathrm{C}$, respectively. For conversion to the conventional thermochemical calorie, one calorie has been taken as equivalent to $4.1840 \mathrm{j}$.

The heat of hydrolysis obtained in table 2 corresponds to the process:

$$
\begin{gathered}
\mathrm{TiI}_{4}(\mathrm{c})+\left[24 \mathrm{H}_{2} \mathrm{SO}_{4}+4 \mathrm{HBr}+2600 \mathrm{H}_{2} \mathrm{O}\right](\mathrm{soln})= \\
{\left[\mathrm{Ti}^{4+}+4 \mathrm{I}^{-}+4 \mathrm{H}^{+}+4 \mathrm{Br}^{-}+24 \mathrm{H}_{2} \mathrm{SO}_{4}+2600 \mathrm{H}_{2} \mathrm{O}\right]} \\
(\text { soln }),(1) \\
\Delta H\left(27^{\circ} \mathrm{C}\right)=-217.81 \pm 0.42 \mathrm{kj} / \text { mole. }
\end{gathered}
$$

\begin{tabular}{|c|c|c|c|c|c|}
\hline Experiment & $\Delta e$ & $\Delta R c$ & $q$ & $\mathrm{TiI}_{4}$ & $-\Delta H\left(27^{\circ} \mathrm{C}\right)$ \\
\hline & $\begin{array}{r}j / o h m \\
24.9 \\
27.5 \\
29.4 \\
26.5 \\
29.9 \\
25.0\end{array}$ & $\begin{array}{l}\text { Ohm } \\
0.073937 \\
.082475 \\
.082103 \\
.071992 \\
.100405 \\
.065496\end{array}$ & $\begin{array}{c}j \\
1616.00 \\
1802.82 \\
1794.84 \\
1573.60 \\
2194.99 \\
1431.51\end{array}$ & $\begin{array}{c}\text { Mole } \\
0.00742699 \\
.00826689 \\
.00822223 \\
.00724680 \\
.01009720 \\
.00655530\end{array}$ & $\begin{array}{l}k j / m o l e \\
217.58 \\
218.08 \\
218.29 \\
217.14 \\
217.39 \\
218.37\end{array}$ \\
\hline \multicolumn{5}{|c|}{$\begin{array}{l}\text { Mean } \\
\text { Standard deviation of the mean }\end{array}$} & $\begin{array}{l}217.81 \\
\pm 0.21\end{array}$ \\
\hline
\end{tabular}

TABLE 2. Results of the experiments on the hydrolysis of $\mathrm{TiI}_{4}$

\subsection{Hydrolysis of $\mathrm{TiBr}_{4}$ in Sulfuric Acid Solution Containing Hydriodic Acid}

The results of the electrical calibration and hydrolysis experiments are given in tables 3 and 4 , respectively. The heat capacity of crystalline $\mathrm{TiBr}_{4}$

\begin{tabular}{|c|c|c|c|}
\hline Experiment & $E$ & $\Delta R c$ & $E_{s}$ \\
\hline $\begin{array}{l}1 \\
2 \\
3 \\
4 \\
5\end{array}$ & $\begin{array}{c}j \\
2064.70 \\
2460.74 \\
2458.30 \\
2459.08 \\
2458.50\end{array}$ & $\begin{array}{l}\text { Ohm } \\
0.094642 \\
.112853 \\
.112683 \\
.112730 \\
.112733\end{array}$ & $\begin{array}{l}\text { j/ohm } \\
21815.9 \\
21804.8 \\
21816.1 \\
21813.9 \\
21808.2\end{array}$ \\
\hline \multicolumn{3}{|c|}{$\begin{array}{l}\text { Mean } \\
\text { Standard deviation of the mean }\end{array}$} & $\begin{array}{r}21811.8 \\
\quad \pm 2.2\end{array}$ \\
\hline
\end{tabular}
was taken as $0.358 \mathrm{j} / \mathrm{g}^{\circ} \mathrm{C}[5]$. The resulting heat of hydrolysis corresponds to the process:

\begin{tabular}{|c|c|c|c|c|c|}
\hline Experiment & $\Delta e$ & $\Delta R c$ & $q$ & $\mathrm{TiBr}_{4}$ & $-\Delta H\left(27^{\circ} \mathrm{C}\right)$ \\
\hline $\begin{array}{l}1 \\
2 \ldots \\
3 \\
4\end{array}$ & $\begin{array}{r}\text { j/ohm } \\
11.9 \\
14.8 \\
14.0 \\
13.6\end{array}$ & $\begin{array}{c}\text { Ohm } \\
0.091141 \\
.110283 \\
.111086 \\
.100716\end{array}$ & $\begin{array}{l}j \\
1989.32 \\
2407.12 \\
2424.65 \\
2198.31\end{array}$ & $\begin{array}{c}\text { Mole } \\
0.00812468 \\
.00984278 \\
.00992151 \\
.00898268\end{array}$ & $\begin{array}{l}k j / \text { mole } \\
244.85 \\
244.56 \\
24.38 \\
244.73\end{array}$ \\
\hline \multicolumn{5}{|c|}{$\begin{array}{l}\text { Mean } \\
\text { Standard deviation of the mean. }\end{array}$} & $\begin{array}{l}244.63 \\
\pm 0.10\end{array}$ \\
\hline
\end{tabular}

$$
\begin{array}{r}
\mathrm{TiBr}_{4}(\mathrm{c})+\left[24 \mathrm{H}_{2} \mathrm{SO}_{4}+4 \mathrm{HI}+2600 \mathrm{H}_{2} \mathrm{O}\right](\mathrm{soln}) \\
=\left[\mathrm{Ti}^{4+}+4 \mathrm{I}^{-}+4 \mathrm{H}^{+}+4 \mathrm{Br}^{-}+24 \mathrm{H}_{2} \mathrm{SO}_{4}\right. \\
\left.+2600 \mathrm{H}_{2} \mathrm{O}\right](\text { soln }) \\
\Delta H\left(27^{\circ} \mathrm{C}\right)=-244.63 \pm 0.20^{\top} \mathrm{kj} / \text { mole. } \\
\text { TABLE 3. Electrical calibration of } \mathrm{TiBr}_{4} \text { system }
\end{array}
$$

TABLE 4. Results of the experiments on the hydrolysis of $\mathrm{TiBr}_{4}$

\subsection{Heats of Dilution of Hydriodic and Hydrobromic Acids}

The heats of dilution of the constant-boiling HI and $\mathrm{HBr}$ solutions in $1-N$ sulfuric acid are given in tables 5 and 6 . Because of the small amount of energy evolved in these experiments, the actual calorimetric system was calibrated just prior to each experiment. The quantity $E_{a}$ denotes the energy equivalent of the actual calorimetric system. The heats of dilution correspond to the following reactions :

$$
\begin{gathered}
{\left[4 \mathrm{HI}+29.1 \mathrm{H}_{2} \mathrm{O}\right](\mathrm{soln})+\left[24 \mathrm{H}_{2} \mathrm{SO}_{4}+2600 \mathrm{H}_{2} \mathrm{O}\right](\mathrm{soln})} \\
=\left[4 \mathrm{HI}+24 \mathrm{H}_{2} \mathrm{SO}_{4}+2629.1 \mathrm{H}_{2} \mathrm{O}\right](\mathrm{soln}), \\
\Delta H\left(27^{\circ} \mathrm{C}\right)=-11.256 \pm 0.088 \mathrm{kj}, \\
{\left[4 \mathrm{HBr}+20.1 \mathrm{H}_{2} \mathrm{O}\right](\mathrm{soln})+\left[24 \mathrm{H}_{2} \mathrm{SO}_{4}\right.} \\
\left.+2600 \mathrm{H}_{2} \mathrm{O}\right](\mathrm{soln}) \\
=\left[4 \mathrm{HBr}+24 \mathrm{H}_{2} \mathrm{SO}_{4}+2620.1 \mathrm{H}_{2} \mathrm{O}\right](\mathrm{soln}) \\
\Delta H\left(27^{\circ} \mathrm{C}\right)=-31.97 \pm 0.24 \mathrm{kj}, \\
\Delta H\left(25^{\circ} \mathrm{C}\right)=-31.54 \pm 0.25 \mathrm{kj} .
\end{gathered}
$$


TABLE 5. Heat of dilution of aqueous hydriodic acid in 1-N sulfuric acid

\begin{tabular}{|c|c|c|c|c|c|}
\hline Experiment & $E_{a}$ & $\Delta R c$ & $q$ & HI & $-\Delta H\left(27^{\circ} \mathrm{C}\right)$ \\
\hline $\begin{array}{l}1 \ldots \\
2 \\
3\end{array}$ & $\begin{array}{l}\text { j/ohm } \\
22100.4 \\
21975.1 \\
22082.4 \\
22075.3 \\
20183.8 \\
20097.1\end{array}$ & $\begin{array}{l}\text { Ohm } \\
0.001374 \\
.000824 \\
.000776 \\
.000572 \\
.003105 \\
.003661\end{array}$ & $\begin{array}{c}j \\
30.37 \\
18.11 \\
17.14 \\
12.63 \\
62.67 \\
73.58\end{array}$ & $\begin{array}{c}\text { Mole } \\
0.0109470 \\
.0064166 \\
.0060461 \\
.0044313 \\
.022347 \\
.026262\end{array}$ & $\begin{array}{c}k j / m o l e \\
2.774 \\
2.822 \\
2.835 \\
2.850 \\
2.804 \\
2.802\end{array}$ \\
\hline \multicolumn{5}{|c|}{$\begin{array}{l}\text { Mean } \\
\text { Standard deviation of the mean }\end{array}$} & $\begin{array}{r}2.814 \\
\pm 0.011\end{array}$ \\
\hline
\end{tabular}

TABLE 6. Heat of dilution of aqueous hydrobromic acid in $1-N$ sulfuric acid

\begin{tabular}{|c|c|c|c|c|c|}
\hline Experiment & $E_{a}$ & $\Delta R c$ & $q$ & $\mathrm{HBr}$ & $-\Delta H\left(27^{\circ} \mathrm{C}\right)$ \\
\hline & $\begin{array}{l}j / 0 h m \\
22098.7 \\
22073.3 \\
20150.6 \\
19801.4\end{array}$ & $\begin{array}{l}\text { Ohm } \\
0.005812 \\
.003218 \\
.014119 \\
.012594\end{array}$ & $\begin{array}{l}j \\
128.44 \\
71.03 \\
284.51 \\
249.38\end{array}$ & $\begin{array}{c}\text { Mole } \\
0.015962 \\
.0088925 \\
.036083 \\
.031394\end{array}$ & $\begin{array}{c}\mathrm{kj} / \mathrm{mole} \\
8.047 \\
7.988 \\
\mathrm{a}(7.885) \\
7.944\end{array}$ \\
\hline \multicolumn{5}{|c|}{$\begin{array}{l}\text { Mean } \\
\text { Standard deviation of the mean }\end{array}$} & $\begin{array}{r}7.993 \\
\pm 0.030\end{array}$ \\
\hline
\end{tabular}

a Experiment number 3 was performed at $25^{\circ} \mathrm{C}$ rather than at $27^{\circ} \mathrm{C}$, and the value was not included in calculating the mean. The value at $25^{\circ} \mathrm{C}$ is required for calculations in sec. 5.2. of this paper. The value of $-\Delta H$ at $25^{\circ} \mathrm{C}$ was taken as $7.885 \mathrm{kj} / \mathrm{mole}$ (from experiment number 3 ). This value is in good agreement with that calculated from the mean value at $27^{\circ} \mathrm{C}$, using an estimated $\Delta C p$ correction.

\subsection{Heat Capacity of Hydrobromic and Hydriodic Acid Solutions}

Because of the lack of data on the heat capacities of aqueous solutions of hydrobromic and hydriodic acid, these values were determined in separate experiments. The effective heat capacity of the empty calorimeter was determined by measuring the heat capacity when filled with pure water, and subtracting the known heat capacity of the water from the observed energy equivalent. The calorimeter was then filled with the same volume of the hydrobromic acid solution, weighed, and the energy equivalent determined. By subtracting the heat capacity of the calorimeter from the observed energy equivalent, the heat capacity of the hydrobromic acid solution was determined. The same procedure was used for determination of the heat capacity of the hydriodic acid solution.

The mean heat capacities obtained for aqueous hydrobromic and hydriodic acid in the range from $25^{\circ}$ to $27^{\circ} \mathrm{C}$ were found to be:

$$
\begin{aligned}
{\left[\mathrm{HBr}+5.0 \mathrm{H}_{2} \mathrm{O}\right], \overline{C p} } & =2.008 \mathrm{j} / \mathrm{g}^{\circ} \mathrm{C} \\
{\left[\mathrm{HI}+7.3 \mathrm{H}_{2} \mathrm{O}\right], \overline{C p} } & =1.845 \mathrm{j} / \mathrm{g}^{\circ} \mathrm{C} .
\end{aligned}
$$

\subsection{Heats of Dilution of Sulfuric Acid}

The heats of dilution of the sulfuric acid solution by the water included in the aqueous halogen acids have been calculated from existing data [5]. The values obtained correspond to the following processes:

$$
\begin{gathered}
29.1 \mathrm{H}_{2} \mathrm{O}(\mathrm{liq})+\left[24 \mathrm{H}_{2} \mathrm{SO}_{4}+2600 \mathrm{H}_{2} \mathrm{O}+4 \mathrm{HI}\right] \text { (soln) } \\
=\left[24 \mathrm{H}_{2} \mathrm{SO}_{4}+2629.1 \mathrm{H}_{2} \mathrm{O}+4 \mathrm{HI}\right](\mathrm{soln}) \\
\Delta H\left(27^{\circ} \mathrm{C}\right)=-0.402 \pm 0.084 \mathrm{kj} \\
20.1 \mathrm{H}_{2} \mathrm{O}(\mathrm{liq})+\left[24 \mathrm{H}_{2} \mathrm{SO}_{4}+2600 \mathrm{H}_{2} \mathrm{O}+4 \mathrm{HBr}\right](\mathrm{soln}) \\
=\left[24 \mathrm{H}_{2} \mathrm{SO}_{4}+2620.1 \mathrm{H}_{2} \mathrm{O}+4 \mathrm{HBr}\right](\mathrm{soln}) \\
\Delta H\left(25^{\circ} \mathrm{C}\right)=-0.301 \pm 0.084 \mathrm{kj}
\end{gathered}
$$

$13.5 \mathrm{H}_{2} \mathrm{O}$ (liq) $+\left[24 \mathrm{H}_{2} \mathrm{SO}_{4}+2600 \mathrm{H}_{2} \mathrm{O}+4 \mathrm{HCl}\right]$ (soln)

$$
\begin{gathered}
=\left[24 \mathrm{H}_{2} \mathrm{SO}_{4}+2613.5 \mathrm{H}_{2} \mathrm{O}+4 \mathrm{HCl}\right](\mathrm{soln}), \\
\Delta H\left(25^{\circ} \mathrm{C}\right)=-0.230 \pm 0.084 \mathrm{kj} .
\end{gathered}
$$

\begin{tabular}{|c|c|c|c|}
\hline Experiment & $E$ & $\Delta R c$ & $E_{s}$ \\
\hline $\begin{array}{l}1 \\
2 \\
3 \\
4 \\
5 \\
6\end{array}$ & $\begin{array}{c}j \\
2907.27 \\
2909.58 \\
2903.97 \\
2910.32 \\
2903.01 \\
2900.78\end{array}$ & $\begin{array}{l}\text { Ohm } \\
0.133216 \\
.133348 \\
.133034 \\
.133377 \\
.133112 \\
.133003\end{array}$ & $\begin{array}{c}\text { j/ohm } \\
21823.4 \\
21819.5 \\
21828.8 \\
21820.3 \\
21808.8 \\
21809.9\end{array}$ \\
\hline \multicolumn{3}{|c|}{$\begin{array}{l}\text { Mean } \\
\text { Standard deviation of the mean }\end{array}$} & $\begin{array}{r}21818.4 \\
\quad \pm 3.2\end{array}$ \\
\hline
\end{tabular}

\subsection{Heat of Hydrolysis of $\mathrm{TiCl}_{4}$}

\begin{tabular}{|c|c|c|c|c|c|}
\hline Experiment & $\Delta e$ & $\Delta R c$ & $q$ & $\mathrm{TiCl}_{4}$ & $-\underset{\mathrm{C})}{-\Delta H\left(27^{\circ}\right.}$ \\
\hline $\begin{array}{l}1 \\
2 \\
3 \\
4 \\
5\end{array}$ & $\begin{array}{r}\text { j/ohm } \\
12.5 \\
15.7 \\
20.7 \\
23.0 \\
12.8\end{array}$ & $\begin{array}{c}\text { Ohm } \\
0.087154 \\
.113947 \\
.146828 \\
.162914 \\
.089692\end{array}$ & $\begin{array}{c}j \\
1902.65 \\
2487.93 \\
3206.59 \\
3558.27 \\
1958.08\end{array}$ & $\begin{array}{c}\text { Mole } \\
0.0078529 \\
.0102626 \\
.0132998 \\
.0147774 \\
.0080773\end{array}$ & $\begin{array}{r}\mathrm{kj} / \text { mole } \\
242.29 \\
242.43 \\
241.10 \\
240.79 \\
242.42\end{array}$ \\
\hline \multicolumn{5}{|c|}{$\begin{array}{l}\text { Mean } \\
\text { Standard deviation of the mean }\end{array}$} & $\begin{array}{l}241.81 \\
\pm 0.36\end{array}$ \\
\hline
\end{tabular}

The results of the electrical calibration and $\mathrm{TiCl}_{4}$ hydrolysis experiments are given in tables 7 and 8 , respectively. The value obtained for the heat of hydrolysis corresponds to the process:

$$
\begin{array}{r}
\mathrm{TiCl}_{4}(\mathrm{liq})+\left[24 \mathrm{H}_{2} \mathrm{SO}_{4}+2600 \mathrm{H}_{2} \mathrm{O}+4 \mathrm{HBr}\right](\text { soln }) \\
=\left[\mathrm{Ti}^{4+}+4 \mathrm{Cl}^{-}+4 \mathrm{H}^{+}+4 \mathrm{Br}^{-}+24 \mathrm{H}_{2} \mathrm{SO}_{4}\right. \\
\left.+2600 \mathrm{H}_{2} \mathrm{O}\right](\text { soln }) \\
\Delta H\left(25^{\circ} \mathrm{C}\right)=-241.81 \pm 0.72 \mathrm{kj} / \text { mole }
\end{array}
$$

TABLE 7. Electrical calibration of the $\mathrm{TiCl}_{4}$ system

TABLE 8. Results of the experiments on the hydrolysis of $\mathrm{TiCl}_{4}$

\subsection{Heat of Hydrolysis of $\mathrm{TiBr}_{4}$ in Sulfuric Acid Solution Containing Hydrochloric Acid}

The results of the electrical calibration and $\mathrm{TiBr}_{4}$ hydrolysis experiments are given in tables 9 and 10 , 
respectively. The value obtained for the heat of hydrolysis corresponds to the process:

$$
\begin{array}{r}
\mathrm{TiBr}_{4}(\mathrm{c})+\left[24 \mathrm{H}_{2} \mathrm{SO}_{4}+2600 \mathrm{H}_{2} \mathrm{O}+4 \mathrm{HCl}\right](\mathrm{soln}) \\
=\left[\mathrm{Ti}^{4+}+4 \mathrm{Br}^{-}+4 \mathrm{H}^{+}+4 \mathrm{Cl}^{-}+24 \mathrm{H}_{2} \mathrm{SO}_{4}\right. \\
\left.+2600 \mathrm{H}_{2} \mathrm{O}\right](\mathrm{soln}) \\
\Delta H\left(25^{\circ} \mathrm{C}\right)=-240.80 \pm 0.62 \mathrm{kj} / \mathrm{mole}
\end{array}
$$

\subsection{Heat of Dilution of Hydrochloric Acid}

The results of the hydrochloric acid dilution experiments are given in table 11. As in the case of the hydriodic and hydrobromic acid dilution experiments, the actual calorimetric system was calibrated electrically for each experiment. The quantity of hydrochloric acid was determined by analysis of the resulting solution after each experiment. The value obtained for the heat of dilution corresponds to the process:

$$
\begin{array}{r}
{\left[4 \mathrm{HCl}+13.5 \mathrm{H}_{2} \mathrm{O}\right](\mathrm{soln})+\left[24 \mathrm{H}_{2} \mathrm{SO}_{4}+2600 \mathrm{H}_{2} \mathrm{O}\right](\mathrm{soln})} \\
=\left[24 \mathrm{H}_{2} \mathrm{SO}_{4}+2613.5 \mathrm{H}_{2} \mathrm{O}+4 \mathrm{HCl}\right](\text { soln }),
\end{array}
$$

\begin{tabular}{|c|c|c|c|}
\hline Experiment & $E$ & $\Delta R c$ & $E_{s}$ \\
\hline $\begin{array}{l}1 \\
2 \\
3 \\
4 \\
5\end{array}$ & $\begin{array}{c}j \\
2910.17 \\
2907.41 \\
2902.85 \\
2902.56 \\
2920.41\end{array}$ & $\begin{array}{c}\text { Ohm } \\
0.132796 \\
.132761 \\
.132508 \\
.132474 \\
.133284\end{array}$ & $\begin{array}{l}\text { j/ohm } \\
21914.6 \\
21899.6 \\
21907.0 \\
21910.4 \\
21911.2\end{array}$ \\
\hline \multicolumn{3}{|c|}{$\begin{array}{l}\text { Mean } \\
\text { Standard deviation of the mean }\end{array}$} & $\begin{array}{r}21908.6 \\
\pm 2.5\end{array}$ \\
\hline
\end{tabular}

\begin{tabular}{|c|c|c|c|c|c|}
\hline Experiment & $\Delta e$ & $\Delta R c$ & $q$ & $\mathrm{TiBr}_{4}$ & $-\Delta H\left(25^{\circ} \mathrm{C}\right)$ \\
\hline 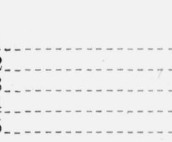 & $\begin{array}{r}\text { j/ohm } \\
13.7 \\
19.4 \\
15.0 \\
11.0 \\
10.8\end{array}$ & $\begin{array}{c}\text { Ohm } \\
0.122050 \\
.146890 \\
.129186 \\
.093681 \\
.099166\end{array}$ & $\begin{array}{c}j \\
2675.62 \\
3221.00 \\
2832.22 \\
2053.45 \\
2173.66\end{array}$ & $\begin{array}{c}\text { Mcle } \\
0.0111647 \\
.0133545 \\
.0117395 \\
.0085122 \\
.0090327\end{array}$ & $\begin{array}{l}\text { kj/mole } \\
239.65 \\
241.19 \\
241.26 \\
241.24 \\
240.64\end{array}$ \\
\hline \multicolumn{5}{|c|}{$\begin{array}{l}\text { Mean } \\
\text { Standard deviation of the mean }\end{array}$} & $\begin{array}{l}240.80 \\
\pm 0.31\end{array}$ \\
\hline
\end{tabular}

$$
\Delta H\left(25^{\circ} \mathrm{C}\right)=-54.241 \pm 0.320 \mathrm{kj} .
$$

\begin{tabular}{|c|c|c|c|c|c|}
\hline Experiment & $E_{a}$ & $\Delta R c$ & $q$ & $\mathrm{HCl}$ & $-\Delta H\left(25^{\circ} \mathrm{C}\right)$ \\
\hline & $\begin{array}{l}j / \mathrm{ohm} \\
22129.1 \\
22125.3 \\
22129.8 \\
22110.0 \\
22111.9\end{array}$ & $\begin{array}{c}\text { Ohm } \\
0.025049 \\
.024841 \\
.024867 \\
.022551 \\
.023629\end{array}$ & $\begin{array}{l}j \\
554.31 \\
549.61 \\
550.30 \\
498.60 \\
522.48\end{array}$ & $\begin{array}{c}\text { Mole } \\
0.041259 \\
.040435 \\
.040749 \\
.036502 \\
.038246\end{array}$ & $\begin{array}{l}k j / \text { mole } \\
13.435 \\
13.592 \\
13.505 \\
13.659 \\
13.610\end{array}$ \\
\hline \multicolumn{5}{|c|}{$\begin{array}{l}\text { Mean } \\
\text { standard deviation of the mean }\end{array}$} & $\begin{array}{r}13.560 \\
\pm 0.040\end{array}$ \\
\hline
\end{tabular}

TABLE 9. Electrical calibration of the $\mathrm{TiBr}_{4}$ system

TABLE 10. Results of the experiments on the hydrolysis of $\mathrm{TiBr}_{4}$

TABLE 11. Heat of dilution of hydrochloric acid in 1-N sulfuric acid

\section{Heats of Formation}

\subsection{Titanium Tetraiodide Compared to Titanium Tetrabromide}

Appropriate combination of eq (1), (2), (3), (4), (5), and (6) leads to the process:

$$
\begin{gathered}
\mathrm{TiI}_{4}(\mathrm{c})+\left[4 \mathrm{HBr}+20.1 \mathrm{H}_{2} \mathrm{O}\right](\text { soln })+9 \mathrm{H}_{2} \mathrm{O}(\mathrm{liq}) \\
=\mathrm{TiBr}_{4}(\mathrm{c})+\left[4 \mathrm{HI}+29.1 \mathrm{H}_{2} \mathrm{O}\right](\text { soln }), \\
\Delta H\left(27^{\circ} \mathrm{C}\right)=+6.00 \pm 0.54 \mathrm{kj} .
\end{gathered}
$$

The heat capacities of the aqueous hydrobromic and hydriodic acid solutions, for the range $25^{\circ}$ to $27^{\circ} \mathrm{C}$, have been taken as 2.008 and $1.845 \mathrm{j} / \mathrm{g}^{\circ} \mathrm{C}$, respectively, from section 4.4 of this paper. The heat capacities of $\mathrm{TiBr}_{4}$ and $\mathrm{TiI}_{4}$ have been taken as 0.358 and $0.235 \mathrm{j} / \mathrm{g}^{\circ} \mathrm{C}$, respectively. By means of these data we obtain for eq (11):

$$
\Delta H\left(25^{\circ} \mathrm{C}\right)=+6.29 \pm 0.55 \mathrm{kj} .
$$

The heat of formation of $\mathrm{HI}$ in $\left[\mathrm{HI}+7.3 \mathrm{H}_{2} \mathrm{O}\right]$ (soln) was taken as $-50.66 \pm 0.04 \mathrm{kj} /$ mole [5], and of $\mathrm{HBr}$ in $\left[\mathrm{HBr}+5.0 \quad \mathrm{H}_{2} \mathrm{O}\right](\mathrm{soln})$ as $-109.96 \pm 0.18 \mathrm{kj} / \mathrm{mole}$ [5].

Thus, we obtain for the difference in heats of formation of $\mathrm{TiI}_{4}$ and $\mathrm{TiBr}_{4}$ :

$$
\begin{aligned}
& \mathrm{TiI}_{4}(\mathrm{c})+2 \mathrm{Br}_{2}(\mathrm{liq})=\mathrm{TiBr}_{4}(\mathrm{c})+2 \mathrm{I}_{2}(\mathrm{c}) \\
& \begin{aligned}
\Delta H\left(25^{\circ} \mathrm{C}\right) & =-230.91 \pm 0.75 \mathrm{kj} / \mathrm{mole} \\
& =-55.19 \pm 0.18 \mathrm{kcal} / \mathrm{mole} .
\end{aligned}
\end{aligned}
$$

Since the heat of formation of $\mathrm{TiBr}_{4}(\mathrm{c})$ has been previously measured [4] by the direct reaction of titanium with bromine $\left[\Delta H f\left(25^{\circ} \mathrm{C}\right)=-616.72 \pm 4.60\right.$ $\mathrm{kj} / \mathrm{mole}$, we obtain the following value for the heat of formation of $\mathrm{TiI}_{4}$ :

$$
\begin{gathered}
\mathrm{Ti}(\text { solid })+2 \mathrm{I}_{2}(\mathrm{c})=\mathrm{TiI}_{4}(\mathrm{c}) \\
\Delta H f^{\circ}\left(25^{\circ} \mathrm{C}\right)=-385.81 \pm 4.64 \mathrm{kj} / \text { mole } \\
=-92.21 \pm 1.11 \mathrm{kcal} / \mathrm{mole}
\end{gathered}
$$

\subsection{Titanium Tetrachloride Compared to Titanium Tetrabromide}

The appropriate combination of eq (6), (7), (8), (9), (10), and (4) leads to the process:

$$
\begin{gathered}
\mathrm{TiBr}_{4}(\mathrm{c})+\left[4 \mathrm{HCl}+13.5 \mathrm{H}_{2} \mathrm{O}\right](\mathrm{soln})+6.6 \mathrm{H}_{2} \mathrm{O}(\mathrm{liq}) \\
=\mathrm{TiCl}_{4}(\mathrm{liq})+\left[4 \mathrm{HBr}+20.1 \mathrm{H}_{2} \mathrm{O}\right](\text { soln })
\end{gathered}
$$$$
\Delta H\left(25^{\circ} \mathrm{C}\right)=-21.76 \pm 1.04 \mathrm{kj} / \text { mole. }
$$ 
The heat of formation of $\mathrm{HCl}$ in $\left[\mathrm{HCl}+3.4 \mathrm{H}_{2} \mathrm{O}\right]$ (soln) is taken as $-151.21 \pm 0.17 \mathrm{kj} /$ mole [5] and of $\mathrm{HBr}$ in $\left[\mathrm{HBr}+5.0 \quad \mathrm{H}_{2} \mathrm{O}\right]$ (soln) is taken as -109.96 $\pm 0.13 \mathrm{kj} /$ mole [5]. Thus, we obtain for the difference in heats of formation of $\mathrm{TiBr}_{4}$ and $\mathrm{TiCl}_{4}$ :

$$
\begin{array}{r}
\mathrm{TiBr}_{4}(\mathrm{c})+2 \mathrm{Cl}_{2}(\mathrm{~g})=\mathrm{TiCl}_{4}(\text { liq })+2 \mathrm{Br}_{2}(\text { liq }) \\
\Delta H\left(25^{\circ} \mathrm{C}\right)=-186.76 \pm 1.34 \mathrm{kj} / \mathrm{mole} \\
=-44.64 \pm 0.32 \mathrm{kcal} / \mathrm{mole} .
\end{array}
$$

This value is in very good agreement with -44.72 $\pm 1.28 \mathrm{kcal}$ for the difference in the directly determined heats of formation of $\mathrm{TiBr}_{4}(\Delta H f=-147.40$ $\pm 1.10)$ and $\mathrm{TiCl}_{4}(\Delta H f=-192.12 \pm 0.65) \quad[3,4]$. This gives added confirmation to the values obtained for the heats of formation of $\mathrm{TiCl}_{4}$ and of $\mathrm{TiBr}_{4}$.

Gross, Hayman, and Levi $[6,7]$ have also reported direct determinations of the heats of formation of $\mathrm{TiBr}_{4}(\Delta H f=-148.10 \pm 0.25 \mathrm{kcal} / \mathrm{mole})$ and $\mathrm{TiCl}_{4}$ $(\Delta H f=-191.45 \pm 0.30 \mathrm{kcal} / \mathrm{mole})$. The difference between these values is $-43.35 \pm 0.35 \mathrm{kcal} / \mathrm{mole}$, which is in reasonably good agreement with the value obtained in the present investigation.

\section{References}

[1] L. Brewer, L. A. Bromley, P. W. Gilles, and N. L. Lofgren, Paper No. 6 in L. L. Quill, ed., Chemistry and metallurgy of miscellaneous materials, thermodynamics, National Nuclear Energy Series IV-19B (McGraw-Hill Book Company, Inc., New York, N.Y., 1950).

[2] J. D. Fast, Z. anorg. u. allgem. Chem. 241, 42 (1939).

[3] W. H. Johnson, R. A. Nelson, and E. J. Prosen, J. Research NBS 62, 49 (1959) RP2928.

[4] R. A. Nelson, W. H. Johnson, and E. J. Prosen, J. Research NBS 62, 67 (1959) RP2932.

[5] F. D. Rossini, D. D. Wagman, W. H. Evans, S. Levine, and I. Jaffe, Selected Values of Chemical Thermodynamic Properties, NBS Circ. 500, (U.S. Government Printing Office, Washington 25, D.C., 1952).

[6] P. Gross, C. Hayman, and D. L. Levi, Trans. Faraday Soc. 51, $626(195.5)$

[7] P. Gross, C. Hayman, and D. L. Levi, Trans. Faraday Soc. 53, $1601(1957)$.

Washington, D. C.

(Paper 63A2-9) 